\title{
PERAN GURU PENDIDIKAN AGAMA ISLAM TERHADAP "PEMBINAAN IBADAH SISWA" KELAS X MADRASAH ALIYAH NEGERI YOGYAKARTA II
}

\author{
Hairiyah dan Ni'matun Khoeriyah \\ PAI STIA Alma Ata Yogyakarta \\ hairiyahhamid@gmail.com
}

\begin{abstract}
ABSTRAK
Penelitian ini membahas mengenai Peran Guru PAI Terhadap Pembinaan Ibadah Siswa Kelas X MAN Yogyakarta II. Penelitian ini merupakan jenis penelitian kualitatif deskripsif. Dalam penelitian ini mengunakan purposive sampling dengan subjek guru PAI dan siswa kelas X dengan jumlah sembilan. Adapun yang menjadi objek adalah bentuk-bentuk pembinaan ibadah dan peran guru PAI. Pengumpulan data mengunakan observasi, wawancara dan dokumentasi. Data dianalisis mengunakan Model Miler and Huberman yaitu pengumpulan data, reduksi data, penyajian data dan menyimpulkan data. Untuk memvaliditasi mengunakan triangulasi. Hasil penelitian ini menunjukkan babrea bentuk-bentuk pembinaan ibadah siswa kelas X MAN Yogyakarta II diantaranya: pembinaan matrikulasi, pesantren sabtu abad (petuah), pengabdian masyarakat. Sedangkan Peran guru PAI diantaranya mengajar, memotivasi, mengarabkan, memfasilitasi, mengevaluasi mendidik.
\end{abstract}

\begin{abstract}
This study discusses the role of Master PAI Against Development of Worship Class X of MAN Yogyakarta II. This study is a qualitative research deskripsif. In this study using purposive sampling with the subject PAI teachers and students of class $X$ with the number nine. As for the objects are forms of worship and the role of the teacher coaching PAI. Collecting data using observation, intervieres and documentation. Data were analyzed using Model Miler and Huberman namely data collection, data reduction, data presentation and conclude data. To memvaliditasi using triangulation. The results of this study indicate that the forms of worship coaching class X MAN Yogyakarta II include: coaching matriculation, schools Saturday ahad (advice), community service. While the role of teachers PAI include teaching, motivating, directing, facilitating, evaluating educational.
\end{abstract}

\section{PENDAHULUAN}

Manusia hidup di bumi bukanlah suatu kehidupan yang tidak mempunyai tujuan, boleh melakukan sesuatu mengikuti keinginan tanpa ada batas dan rasa tanggung jawab, melainkan manusia diciptakan mempunyai suatu tujuan yang telah ditetapkan oleh Allah. Tugas dan tanggung jawab manusia sebenarnya telah jelas sebagaimana terkandung di dalam Al-Qur'an yaitu melaksanakan ibadah. Hal ini seperti firman Allah Surat Adz-Dzariyat ayat 56

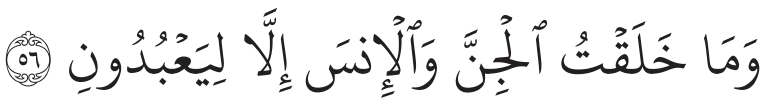

Artinya: "Dan tidak menciptakan jin dan manusia melainkan supaya mereka menyembab$K u$ ”.(Adz Dzariyat:56)
Ibadah tidak terbatas pada masalah ritual saja, tetapi mencakup seluruh aspek kehidupan dalam hubungan dengan individu, sosial, dan ritual yang dilandasi oleh ajaran Islam. Ibadah juga bertujuan agar manusia mempunyai sifat yang terpuji, baik hubungannya dengan Allah maupun sesama manusia serta lingkunganya. ${ }^{1}$ Pada kenyataanya di masa sekarang masih banyak para remaja yang tidak melaksanakan ibadah bahkan melakukan perilaku penyimpangan. Hal tersebut karena mereka mengalami krisis moral, krisis spiritual, krisis keteladanan yang berakibat pada pembodohan dan kehancuran. ${ }^{2}$ Maka dari itu

${ }^{1}$ Muhammad Qutub, Sistem Pendidikan Islam (Bandung, Al-Ma'arif: 1984) hlm. 21-22

${ }^{2}$ E. Mulyasa, Menjadi Guru Profesional Menciptakan Pembelajaran Kreatif dan Menyenangkan (Bandung, Remaja 
pendidikan agama (ibadah) memiliki peran penting karena dapat menumbuhkembangkan kecerdasan spiritual, menyebabkan pengaruh-pengaruh positif yang luar biasa dipandang dari kemampuannya, mampu menciptakan kebahagian atau memperbaiki hubungan-hubungan sosial, atau mengurangi bahkan menghapus sama sekali kesulitan-kesulitan yang sebelumnya tidak terhindar di dalam sistem dunia. ${ }^{3}$ Hal tersebut mendorong perlunya pembinaan ibadah.

Pelaksanaan pembelajaran pendidikan agama yang berlangsung di sekolah masih mengalami banyak kelemahan, diantaranya pendidikan hanya memperhatikan aspek kognitif semata dan mengabaikan pembinaan aspek afektif dan konatifvolitif, yaitu tekad untuk mengamalkan nilai-nilai agama. ${ }^{4}$ Selain itu waktu pembelajaran PAI masih kurang dan bekal pengetahuan agama siswa berbeda-beda sehingga pembinaan di sekolah sangat penting. ${ }^{5} \mathrm{Hal}$ ini senada dengan Zakiah Darajat (1982) menjelaskan bahwa:

"Apabila pendidikan agama diabaikan di sekolah, maka didikan agama yang diterima dirumah tidak akan berkembang, babkan mungkin terhalang, apalagi jika rumabtangga kurang dapat memberikan pembinaan agama sesuai aturannya ${ }^{6}$. Apabila seorang anak pada masa itu tidak mendapat pendidikan tentang agama dan tidak mempunyai pengalaman keagamaan, maka nanti setelah derwasa cenderung kepada sikap negative terhadap agama"?

Menjadi tugas semua pihak, terutama dalam hal ini adalah lembaga pendidikan sekolah.

Rosdakarya: 2007) hlm. 203

${ }^{3}$ Abuddin Nata Haji, Ilmu Pendidikan Islam dengan Pendeketan Multidisiplin: Normatif Perenialis, Filsafat, Psikologi, Sosiologi,Manajemen, Teknologi, Informasi, Kebudayaan, Politik, Hukum (Jakarta, Raja Grafindo Persada:2010) hlm.38

${ }^{4}$ Nusa Putra dan Santi Lisnawati, Penelitian Kualitatif Pendidikan Agama Islam (Bandung, Remaja Rosdakarya: 2012) hlm.8

${ }^{5}$ Fajar Basuki Rahmat, Guru Pendidikan Agama Islam Fiqih MAN Yogyakarta II wawancara tanggal 10 -Oktober-2015

${ }^{6}$ Zakiah Darajat, Peranan Agama dalam Kesehatan Mental (Jakarta, Gunung Agung: 1982) hlm. 71

Zakiah Darajat, Ilmu Jiwa Agama (Jakarta, Bulan Bintang: 2002) hlm. 69
Dalam hal ini guru mempunyai peran dalam membantu pembinaan ibadah karena seorang guru tidak hanya bertugas mengajar, melainkan juga mendidik budi pekerti siswa. Tidak terkecuali dengan Guru Pendidikan Agama Islam (PAI) yang mempunyai peran penting terhadap pembinaan ibadah agar siswa bersemangat dan antusias dalam mengamalkan ibadah, baik di sekolah maupun di luar sekolah.

Menyerahkan tanggung jawab terhadap pembinaan ibadah siswa kepada guru PAI saja tentu tidak cukup, melainkan juga menjadi tanggung jawab seluruh komponen sekolah. Dalam praktiknya, tidak semua guru pendidikan agama melakukan pembinaan ibadah pada siswa. Walaupun demikian, tidak semua sekolah seperti itu, salah satunya di MAN Yogyakarta II guru PAI melakukan pembinaan ibadah, bahkan dilengkapi dengan buku pembinaannya yang berisi materi pembinaan ibadah mulai dari kebiasaan emas (the golden habits), thaharah, shalat, doa-doa harian, materi tadarus, hafalan Alqur'an dan bagian terakhir adalah halaman penilaian siswa serta format pengabdian ibadah di masyarakat. ${ }^{8}$

Berdasarkan hasil observasi yang dilakukan peneliti bahwa pembinaan ibadah di MAN Yogyakarta II sudah dilaksanakan pada semua siswa, tidak terkecuali kelas X. ${ }^{9}$ Buktinya bahwa semua siswa mengikuti pembinaan ibadah yang telah dijadwalkan, yaitu pembinaan matrikulasi (hafalan), pesantren Sabtu Ahad dan pengabdian masyarakat. Namun pada kenyataanya berdasarkan hasil wawancara bahwa sebagian siswa tidak melaksanakan ibadah shalat berjamaah apabila tidak diingatkan dan dipaksa oleh guru, masih adanya siswa yang belum lancar membaca Al-qur'an, dan ada siswa yang tidak datang pada saat pembinan ibadah yang sudah dijadwalkan. ${ }^{10}$ Hal tersebut mendorong peneliti untuk melakukan penelitian lebih lanjut terhadap

${ }^{8}$ Fajar Basuki Rahmat dkk, Buku Pembinaan Ibadah Madrasah Negeri Yogyakarta II (Yogyakarta, MAN Yogyakarta II: 2015) hlm. iii-v

${ }^{9}$ Hasil Observasi, Pembinaan Ibadah Siswa , tanggal 26 Juni 2015

${ }^{10}$ Hanif Latif, Guru Al-Quran Hadist dan Selaku Pembinaan Ibadah Kelas X MIA 1, wawancara, tanggal 07-Oktober-2015 
peran guru PAI, sehingga berdasarkan latar belakang tersebut maka peneliti ingin meneliti lebih lanjut mengenai Peran Guru Pendidikan Agama Islam Terhadap "Pembinaan Ibadab Siswa" Kelas X MAN Yogyakarta II.

\section{METODOLOGI PENELITIAN}

Penelitian ini merupakan jenis penelitian kualitatif deskripsif. Dalam penelitian ini mengunakan purposive sampling dengan subjek guru PAI dan siswa kelas X IIS 1, X MIA 1, X MIA 2, X IIK berjumlah sembilan. Adapun yang menjadi objek adalah bentuk-bentuk pembinaan ibadah, peran guru PAI serta faktor pendukung, penghambat dalam pelaksanaan pembinaan ibadah kelas X. Pengumpulan data mengunakan observasi, wawancara dan dokumentasi. Data dianalisis mengunakan Model Miler and Huberman yaitu pengumpulan data, reduksi data, penyajian data dan menyimpulkan data. ${ }^{11}$ Untuk memvaliditasi mengunakan triangulasi.

\section{HASIL PENELITIAN}

\section{Bentuk-bentuk pembinaan ibadah siswa kelas $\mathrm{X}$}

Pembinaan ibadah yang dimaksud di sini adalah pembinaan yang terprogram/terstruktur secara resmi. Dalam pembinaan ibadah ini siswa didorong lebih banyak memiliki hafalan dan mengamalkan ibadah sesuai dengan ajaran islam.

Adapun bentuk pembinaan ibadah siswa kelas X MAN Yogyakarta II berdasarkan buku pembinaan ibadah mencakup tiga diantaranya: ${ }^{12}$

\section{Pembinaan matrikulasi}

Pembinaan matrikulasi kelas X dilaksanakan setelah shalat ashar sampai pukul 15.55 WIB (wajib). Pembinaan matrikulasi dapat dilaksanakan di luar jam, semisal jam istirahat (antara siswa dan guru PAI ada waktu luang). Hal ini biasanya dilakukan jika mendekati semesteran dan siswa belum memenuhi $75 \%$ dari yang sudah ditarget. ${ }^{13}$ Dari pihak guru PAI sebenarnya sudah

\footnotetext{
${ }^{11}$ Sugiyono, Metode Kuantitatif Kualitatif dan $R$ e $R$ (Bandung, Alfabeta: 2014) hlm.246-253

${ }^{12}$ Fajar Basuki, dkk, Buku Pembinaan Ibadah Madrasah Aliyah Negeri Yogyakarta...,hlm. 47-54

${ }^{13}$ Supriyadi, Guru Fikih dan Pendamping Pembinaan
}

menawarkan bahwa pembinaan matrikulasi bisa dilaksanakan diluar jam. ${ }^{14}$

Adapun materi pembinaan ibadah siswa kelas X, semester ganjil diantaranya: 1) hafalan juz surat-surat al-qur'an juz 30 mulai dari surat $\mathrm{AN}$ Nas, Al-Falaq, Al-Ikhlas, Al-Lahab, AN-Nashr, Al-Kafirun, Al-Kautsar, Al-Maun, Al-Quaraisy, Al-Fiil, Al-Humazah, Al-Ashr, AT-Takasur, AlQari'ah, Al-Adiyat, Al-Zalzalah 2) lafal adzan, iqomah bagi siswa putra sedangkan putri adalah iqomah saja 3) materi hafalan doa-doa harian mulai doa akan belajar, doa sesudah belajar, doa setelah shalat dhuha, doa penutup majelis, doa memohon kebaikan dunia akhirat, doa untuk menjenguk orang sakit, doa syukur memohon kekuatan beramal shalih. Sedangkan pembinaan matrikulasi kelas X semester genap 1) hafalan surat-surat Al-qur'an juz 30 mulai dari surat Al-Bayinah, Al-Alaq, At-Tiin, Al-Insyirah, AdhDhuha, Al-Lail, Asy-Syam, Al-Balad, Al-Fajr, Al-Ghasiyah, Al-A'la. 2) hafalan bacaan shalat mulai dari Iftitah, Al-Fatihah, Ruku/Sujud, I'tidal, Duduk antara dua sujud, Tasyahud, Dzikir ba'da Shalat. ${ }^{15}$

\section{Pesantren Sabtu Abad (Petuab)}

Pesantren sabtu ahad berawal mulai tahun 2010 bernama qiyamul lail. Sejak tahun 2013 menjadi pesantren Sabtu Ahad (petuah). ${ }^{16}$ Perantren Sabtu Ahad adalah kegiatan yang di mulia pada hari Sabtu setelah pulang sekolah sampai Ahad pagi pukul 06.00 WIB. Pembinaan ini bertujuan agar siswa aqidahnya baik, akhlaknya baik sehingga disiplin belajar, tutur katanya baik, baik bergaul dengan orang tua, dan merealisasikan kegiatan pembinaan ibadah. ${ }^{17}$

Dalam pesantren Sabtu Ahad pembinanya hanya satu jenis siswa, misalnya Sabtu ini siswa kelas X putri, Sabtu depan adalah untuk siswa kelas X putra. Pembimbing dalam pesantren

Ibadah Kelas X IIK, wawancara-04-November-2015

${ }^{14}$ Kurnia Ikhlasul Amal, Siswa Selaku Mantan Ketua Osis, wawancara,tanggal 10-Oktober-2015

${ }^{15}$ Fajar Basuki dkk, Buku Pembinaan Ibadah Madrasah Aliyah Negeri Yogyakarta II... hlm 47-50

${ }^{16}$ Reva Yondra, Guru Fikih dan Pendamping Pesantren Sabtu Ahad, wawancara tanggal 07-Oktober2015

${ }^{17}$ Reva Yondra, Guru Fikih dan Pendamping Pesantren Sabtu Ahad, wawancara tanggal 05-November-2015 
Sabtu Ahad hanya membimbing maksimal 10 siswa. Kegiatan pembinaan ibadah yang dilakukan yaitu mulai dari shalat berjamah, peningkatan keagamaan baik dari bacaan hafalan al-qur'an (juz 30), doa-doa harian, bacaan-bacaan sholat, penguatan aqidah dengan ibadah (di isi penceramah dari luar), bimbingan atau curhat, sholat qiyamul lail, sholat subuh, kultum, tadarus bersama-sama dan terakhir adalah bersih-bersih dan penutup. ${ }^{18}$

Adapun metode pembinaan ibadah berdasarkan hasil pengamatan peneliti mengunakan metode privat (sorogan) dan metode pembiasaan. Metode privat (sorogan) dilakukan pada saat pembinaan matrikulasi yang dilakukan setelah shalat ashar, maghrib dan isya. Sedangkan metode pembiasaan dalam hal ini dengan membiasakan shalat berjamaah baik shalat fardhu, shalat sunah (qiyamul lail) dan tadarus. ${ }^{19}$

Pembimbing pesantren Sabtu Ahad sudah terjadwal baik siswa putri dan putra. Pembimbing pesantren sabtu ahad putri diantaranya: Supriyadi S.Pd.I, Reva Yodra S. Pd.I, Bardiana Dwi S.Pd.I, Roynah S.Pd, Dyah Estuti Trihartini S.Pd, Yuni Fatmawati M.Pd.I, Dhani Melyana S.Pd, Endang Wahyudi S.Pd, Retno Nur Wulandari SE, Nur Fatimah S.Pd. Sedangkan jadwal pembimbing pesantren Sabtu Ahad putra diantaranya: Puguh Mahardika S.Pd.I, Somadi S.Pd, Drs. Bambang Sunaryo, Fajar Rahmadi S.Pd., M.Sc, Drs H. Daelami, NB.Jauhari arifin S.Pd.I, Dra Hj Ha'nah Hanum, Anita Dwi Rossely S.Pd. ${ }^{20}$ Pada kenyatanya selain guru yang tertera di atas, guru PAI yang tidak terjadwal datang membantu, walaupun berdasarkan pengamatan peneliti, datang terlambat. ${ }^{21}$

\section{Pengabdian masyarakat}

Guru bertanggung jawab dalam membina hubungan dengan masyarakat dengan

\footnotetext{
${ }^{18}$ Jadwal Acara Pesantren Sabtu Ahad (petuah) Man Yogyakarta II.

${ }^{19}$ Hasil Observasi Pesantren sabtu ahad, tanggal 24 -Oktober-2015

${ }^{20}$ Dokumen Surat Tugas MAN Yogyakarta No Ma.12.2/PP.00.6/1150/2015

${ }^{21}$ Hasil Obbservasi Pesantren Sabtu Ahad, tanggal 24 dan 31- Oktober-2015
}

menempatkan sekolah sebagai integral dari masyarakat serta sekolah sebagai pembaharu masyarakat, untuk itu guru dituntut dapat menumbuhkan partisipasi masyarakat dalam meningkatkan pendidikan dan pengajaran di sekolah. ${ }^{22}$ Hal ini seperti MAN Yogyakarta II mengadakan program pembinaan ibadah pengabdian masyarakat untuk semua siswa.

Pengabdian masyarakat dalam hal ini adalah salah satu program pembinaan ibadah untuk merealisasikan kompetensi keagamaan secara. Pengabdian masyarakat ini wajib dilakukan setiap siswa setelah adanya pembekalan. Adapun pembelakalan itu hanya satu kali pertemuan. Pendamping pembinaan memberikan gambaran secara umum baik materi, metode yang digunakan dan tata cara yang baik saat siswa terjun di masyarakat ${ }^{23}$

Metode yang digunakan adalah praktek lapangan. Siswa diberi tugas untuk praktek langsung mulai dari adzan dan iqomah (putra), kultum, khutbah jum'at, shalat jenazah, mengajar TPA, membantu panitia perayaan hari besar islam (PHBI) di masyarakat. Setelah itu siswa meminta paraf takmir, guru, orangtua, dan menuliskan tempat pengabdiannya sebagai bukti. ${ }^{24}$

\section{Peran guru PAI terhadap pembinaan ibadah siswa kelas $\mathrm{X}$}

Berbicara tentang peran guru PAI dalam pembinaan ibadah tentunya tidak lepas pada peran guru secara umum, baik menurut UndangUndang Repuplik Indonesia Nomor 14 tahun 2005 tentang Guru dan Dosen pasal 1 bahwa pendidik professional memiliki peran utama mendidik, mengajar, membimbing, mengarahkan, melatih, menilai dan mengevaluasi siswa pada pendidikan anak usia dini, jalur pendidikan formal, pendidikan dasar, dan pendidikan menengah. ${ }^{25}$ Sedangkan menurut Sardiman

${ }^{22}$ Buchari Alma, Guru Profesional Menguasai Metode dan Terampil Mengajar (Bandung, Alfabeta : 2010) hlm. 133

${ }^{23}$ Hanif Latif, Guru Al-quran Hadist dan Pendamping Pembinaan Ibadah kelas X MIA 1, wawancara 05-November-2015

${ }^{24}$ Fajar Basuki Rahmat dkk, Buku Pembinaan Ibadah Madrasab Aliyah Negeri Yogyakarta II..., hlm.50

${ }^{25}$ Undang-Undang Repuplik Indonesia No 14 Tahun 2005, Tentang Guru dan Dosen..., hlm.1-2 
(2000) menjelaskan guru berperan dalam kegiatan belajar mengajar diantaranya sebagai informator, organisator, motivator, pengarahan, inisiator, transmitter, fasilitator, mediator dan evaluator. ${ }^{26}$ Sementara itu menurut Zuhairini dkk, memahami guru agama islam merupakan pendidik yang mempunyai tanggung jawab dalam membentuk kepribadian Islam siswa serta bertanggung jawab terhadap Allah SWT. Dia membagi tugas guru agama islam sebagai berikut: mengajarkan ilmu pengetahuan, menanamkan keimanan dalam jiwa anak, mendidik anak agar taat menjalankan agama, mendidik anak agar berbudi pekerti yang mulia. ${ }^{27}$ Hal tersebut dikuatkan bahwa guru agama berbeda dengan guru bidang studi lainya.

Guru agama disamping melaksanakan tugas pengajaran yaitu memberitahukan pengetahuan keagamaan, ia juga melaksanakan tugas pengajaran dan pembinaan bagi siswa, ia membantu pembentukan kepribadian, pembinaan akhlak serta menumbuhkembangkan keimanan dan ketaqwaan. ${ }^{28}$

Jadi peran guru PAI sama dengan guru umum hanya dalam aspek-aspek tertentu ada perbedaan, sebab guru PAI lebih dominan memiliki tanggung jawab lebih dalam mengarahkan siswa untuk mengamalkan ajaran islam.

Setelah melakukan penelitian dengan berpedoman landasan teori di atas hanya sebagian peran guru PAI yaitu terdapat enam peran guru PAI dalam pembinaan ibadah siswa kelas X MAN Yogyakarta II. Adapun enam peran guru PAI antara lain mengajar, motivator, mengarahkan, fasilitator, mengevaluasi, dan mendidik.

\section{Mengajar}

Mengajar merupakan kegiatan mutlak yang memerlukan keterlibatan antara guru dan siswa. Berdasarkan hasil pengamatan peneliti guru PAI dalam pembinaan matrikulasi dilaksanakan sesuai dengan kelas masing-masing seperti dalam KBM. Guru PAI membuka pembelajaran dengan

\footnotetext{
${ }^{26}$ Sardiman, Interaksi dan Motivasi Belajar Mengajar... hlm. 144

${ }^{27}$ Zuhairini dkk, Metodik Kbusus Pendidikan Agama ...,hlm. 34

${ }^{28}$ Zakiyah Darajat, Pendidikan Islam Dalam Keluarga dan Sekolab ..., hlm. 99
}

memberikan pengetahuan kaidah-kaidah tajwid berkaitan makbarijul buruf, shifatul buruf, abkamul buruf, maddi wal ibtida, abkamul wakaf wal ibtida dan pada saat siswa menyetorkan hafalan secara individu. ${ }^{29}$ Sedangkan dalam pesantren Sabtu Ahad, guru PAI memberikan pengetahuan agama yang mendalam sesuai permasalahan siswa pada saat "curah gagasan". 30

\section{Memotivasi}

Motivasi sangatlah diperlukan bagi siswa dalam pembinaan ibadah. Berdasarkan hasil pengamatan peneliti guru PAI dalam pembinaan matrikulasi memberikan motivasi dengan menjelaskan manfaat menghafal dan memberikan cara menghafal yang tepat. Dalam pesantren Sabtu Ahad, guru PAI mendatangkan penceramah dari luar dengan tema pemberian motivasi aqidah dengan ibadah selama satu jam. ${ }^{31}$ Setelah pemberian motivasi dari luar selesai, guru PAI membimbing, memberi dan memberikan solusi berkaitandengan permasalahanya.

\section{Mengarabkan}

Guru PAI dalam pembinaan ibadah melakukan pengarahan dalam arti memposisikan sebagai orang yang mengarahkan, menuntun targettarget hafalan yang harus dicapai, mulai hafalan surat-surat Al-qur'an (juz 30), lafal adzan, iqomah, doa-doa harian. Hal ini Senada yang disampaikan bapak Hanif Latif selaku pendamping pembinaan ibadah kelas X MIA II yang menyatakan:

\section{"Awal masuk masing-masing pembimbing memberikan pergertian babwa anak kelas $X$ wajib melakukan hafalan ini, sistemnya seperti ini, kalau menghafalkan lancar bagus seperti ini, kurang seperti ini, jika tidak bisa seperti ini, semua ada dibuku pembinaan ibadab". ${ }^{32}$}

Guru PAI menyimak dengan seksama sehingga jika terjadi kesalahan guru PAI membenarkan dan mencontohkan secara langsung pada saat itu juga.

\footnotetext{
${ }^{29}$ Hasil Observasi, tanggal 12-Oktober-2015

${ }^{30}$ Hasil Observasi, tanggal 24-Otober-2015

${ }^{31}$ Hasil Observasi, tanggal 25-Oktober-2015 .

${ }^{32}$ Hanif Latif , Guru Qur'an Hadis, Tafsir dan Pendamping Pembinaan Ibadah Kelas X MIPA 2, wawancara tanggal 05-November-2015.
} 
Hal ini sebagaimana yang disampaikan bapak Hanif Latif selaku pendamping pembinaan ibadah kelas X MIAII bahwa:

"Satu persatu siswa didampingi oleb guru pembimbing pembinaan ibadah masing-masing, siswa diawasi apakab hafalan sudab lancar atau belum, siswa diawasi apakab hafalannya sudab benar/tidak, sesuai mabrrojnya atau belum, siswa diazeasi cara pengucapanya betul atau tidak". ${ }^{33}$

\section{Memfasilitasi}

Fasilitator adalah seseorang yang memfasilitasi guna mencapai tujuan yang sudah ditentukan. Tidak terkecuali guru PAI MAN Yogyakarta II yang berperan sebagai fasilitator. Dalam artian guru PAI memberikan fasilitas / kemudahan dalam proses pembinaan ibadah kepada siswa dengan harapan tercapainya targettarget yang sudah ditentukan.

Peran guru PAI sebagai fasilitator berkaitan dengan pembinaan ibadah siswa, salah satunya dengan menulis buku panduan pembinaan ibadah yang berjudul" Buku Pembinaan Ibadah Siswa Madrasab Aliyah Negeri Yogyakarta II" buku ini disusun oleh beberapa guru PAI diantaranya Fajar Basuki Rahmat S.Ag, H. Riza Faozi S.Pd.I, Supriyadi SPd.I, Reva Yondra, SPd.I, Hanif Latif,S. Pd.I, Siti Daimah, S. Ag, Muthamainnah, S.Ag, Yuni Fatmawati, M. Pd.I. Dalam buku pembinaan ibadah berisi semua materi pembinaan ibadah mulai dari kelas X, XI, XII baik surat al-quran (juz30), doa-doa harian, lafal adzan dan iqomah, bacaan shalat fardhu, bacaan shalat jenazah disertai arti dan beberapa keterangan berkaitan materi tersebut. Selain itu ada petunjuk target-target hafalan yang harus dipenuhi siswa selama di MAN Yogyakarta II dan ada petunjuk kriteria dalam penilaian.

Adanya buku pembinaan ibadah tersebut dapat memberikan fasilitas salah satunya kemudahan untuk menghafal semua materi yang sudah ditargetkan. Sebagaimana peneliti observasi bahwa semua siswa sambil menunggu temannya menghafal secara privat (sorogan) di depan guru PAI, siswa lainnya menghafal dengan buku panduan

${ }^{33}$ Hanif Latif ,Guru Qur'an Hadis, Tafsir dan Pendamping Pembinaan Ibadah Kelas X MIPA 2 tanggal 5-November-2015. pembinaan ibadah. ${ }^{34} \mathrm{Hal}$ ini dikuatkan dengan hasil wawancara siswa kelas X MIA 1 bahwa belajar menghafal baik surat-surat juz ama, doa-doa harian memakai buku pedoman pembinaan ibadah siswa. ${ }^{35}$

\section{Mengevaluasi}

Evaluasi pembelajaran merupakan salah satu komponen sistem pendidikan yang terintegrasikan dalam sistem persekolahan sebagai suatu lambang keberhasilan dan kemajuan belajar siswa. ${ }^{36}$ Evaluasi sangatlah penting karena evaluasi lebih dari hanya sekedar untuk menentukan angka keberhasilan belajar, tetapi yang paling penting kepribadianya. Guru PAI dalam hal ini mengevaluasi hafalan mulai surat-juz ama, doadoa harian, adzan, iqomah yang dilaksanakan setiap setelah siswa selesai menyetorkan hafalan dengan pemberian nilai sesuai kriteria yang sudah ditentukan. Adapun kriteria penilaian yaitu:

\section{"Pedoman kriteria penilaian sudab ditentukan diantaranya Jika bacaan lancar, makbraj baik, cara pengucapanya bagus dan panjang-pendeknya bacaanya benar nilainya A. Jika bacaanya lancar, makbraj baik, cara pengucapanya cukup bagus, dan panjang-pendeknya bacaanya benar nilanya A-Jika bacaan lancar, makbraj cukup baik, cara pengucapanya cukup bagus dan panjang-pendek bacaanya benar nilai $B^{+}$. Jika bacaan cukup lancar, makbraj cukup, cara pengucapanya cukup bagus dan panjang-pendeknya cukup benar nilai $B$, Jika bacaan belum lancar, makbraj kurang baik, cara pengucapanya belum bagus dan panjang- pendek bacaanya belum lancar nilai $B-$-“.37}

Hal ini seperti yang disampaikan bapak Hanif Latif selaku pendamping pembinaan ibadah kelas X MIA II bahwa penilaian siswa dilakukan setelah selesai menyetorkan hafalanhafalan, guru menilai di daftar pemantauan guru

${ }^{34}$ Hasil Observasi kelas X MIA 1, tanggal 19-Oktober-2015

${ }^{35}$ Jihan Ahnaf Dwi Cahyan, Siswa Kelas X MIPA 1, wawancara tanggal 04-November-2015

${ }^{36}$ Hamzah B. Uno dan Masri Kuadrat, Mengelola Kecerdasan Dalam Pembelajaran Sebuab Konsep Pembelajaran Berbasis Kecerdasan (Jakarta, Bumi Aksara: 2009) hlm.84

${ }^{37}$ Fajar Basuki Rahmat dkk, Buku Pembinaan Ibadah Madrasab Aliyah Negeri II... hlm. 83 
dan di buku panduan pembinaan ibadah siswa. ${ }^{38}$ Penilaian tersebut dilakukan untuk mengukur, memberi gambaran kemampuan siswa setiap kali menyetorkan hafalan, apakah siswa memiliki kemampuan pandai, sedang, kurang atau cukup.

Selain memberikan nilai, guru PAI juga mengevaluasi dalam arti tidak hanya melihat sampai tidaknya hafalan yang sudah ditargetkan, akan tetapi menyangkut perilakunya. Salah satunya dalam program pengabdian masyarakat dan pesantren Sabtu Ahad, disitulah guru mengevaluasi apakah nilai hafalan, baik suratsurat Al-qur'an, doa-doa harian, azdan, iqomah, bacaan shalat itu terealisasikan dengan baik atau tidak. Berdasarkan hasil pengamatan peneliti, tidak berhenti disitu saja sebelum pembelajaran KBM di mulai, guru PAI mengevaluasi pada saat tadarus. ${ }^{39}$ Seperti yang disampaikan bapak Supriyadi selaku pendamping pembinaan ibadah kelas X IIK bahwa:

"Setiap hari sebelum kegiatan pembelajaran dimulai diadakan tadarus selama 15 menit secara bersama-sama. Disitulah guru memantau bacaannya, tapi tetap jika terjadi kesalaban guru mengarabkan dalam artian membenarkan bacaannya. Selain itu juga ada kegiatan shalat dhuba sesuai jadwalnya”. ${ }^{40}$

\section{Mendidik}

Dalam pembinan ibadah di MAN Yogyakarta II, guru PAI memiliki peran yaitu mendidik. Mendidik dalam arti, guru PAI membiasakan melaksanakan ibadah, memberi contoh, dan memberi sangsi.

Guru PAI mendidik pada pembinaan matrikulasi dan persantren sabtu ahad dengan memberikan contoh secara langsung dan membiasakan menjalankan ibadah. Mendidik dengan pembiasaan ini meliputi ketepatan waktu dalam menjalankan ibadah mulai shalat wajib dan shalat sunah shalat qiyamul lail berjamah dan

${ }^{38}$ Hanif Latif Guru Qur'an Hadis, Tafsir dan Pendamping Pembinaan Ibadah, wawancara tangga 1 5-November-2015

${ }^{39}$ Hasil Observasi Kelas X IBB Tanggal 17-Oktober-2015

${ }^{40}$ Supriyadi, Guru fikih dan Pendamping Pembinaan Ibadah Kelas X IIK, wawancara tanggal 07-Oktober-2015. tadarus. Berbeda dengan pengabdian masyarat guru PAI memberikan tugas untuk terjun di masyarakat. Hal ini senada dengan yang disampaikan Reva Yondra selaku salah satu pembimbing pesantren Sabtu Ahad dan sekertaris hafalan bahwa:

\begin{abstract}
"Dalam pembinaan ibadah, khususnya guru PAI memiliki tanggung jawab besar berkaitan dengan ibadah. Dalam hafalan (bafalan) guru memberi contoh secara langung, setelab itu membaca secara bersama-sama bacaanya. Sedangkan untuk pesantren Sabtu Abad, guru PAI lebib menekankan pada siswa agar melaksanakan shalat wajib berjamaab dan qiyamul lail. Berbeda dengan pengabdian masyarakat guru hanya memberikan pembekalan sebelum terjun di masyarakat, setelab itu guru akan melibat dari formatnya yang dibawa siswa. Pengabdian masyarakat ini bertujuan apakab pembinaan itu terealisasikan dengan baik atau tidak, walaupun saat ini masib mengunakan metode paksaan, jika siswa tidak memenubi target baik itu hafalan, jika ada siswa tidak mengikuti pesantren Sabtu Abad tanpa alasan maka wajib mengikuti pesantren Sabtu Ahad bersama kakak kelas ataupun adik kelas, begitu juga pengabdian masyarakat tidak terpenubi, maka tidak bisa mengambil kartu ujian". ${ }^{41}$
\end{abstract}

Dalam mendidik, guru PAI juga menerapkan beberapa aturan. Bagi yang melakukan pelanggaran akan dikenakan hukuman sesuai aturan yang disepakati. Salah satunya yang peneliti lihat adalah siswa diberi tugas untuk menulis ayat-ayatAl-qur'an. ${ }^{42}$

\section{Faktor pendukung dan penghambat}

Adapun beberapa faktor yang menjadi penghambat dan pendukung pembinaan ibadah siswa kelas X MAN Yogyakarta II diantaranya adalah:

a. Faktor pendukung pembinaan ibadah siswa kelas X diantaranya:

1) Visi " abtu Ahad (petuah) dimana siswa bermalam di sekolah setiap Sabtu sore sampai Ahad pagi pukul 06.00 WIB dengan

${ }^{41}$ Reva Yodra, Guru Fikih dan Pendamping pesantren sabtu ahad, wawancara tanggal 24-Oktober-2015

${ }^{42}$ Hasil Observasi, Pembinaan Matrikulasi, tanggal 19- Oktober-2015 
melaksanakan rangkaian kegiatan sesuai jadwal. Ketiga, pengabdian masyarakat dimana siswa ditekankan untuk praktek secara langsung di masyarakat mulai adzan iqomah (putra), kutbah jumat, kultum (kuliah tujuh menit), mengajar TPA, sholat jenazah, membantu dalam peringatan hari besar islam (PHBI) dengan membawa format yang sudah disiapkan dari pihak sekolah. Dalam pengabdian masyarakat siswa diberikan kesempatan untuk praktek sesuai format dengan batas akhir mendekati semester 2 .

Dalam pembinaan ibadah, guru PAI mengunakan beberapa metode. Metode privat (sorogan) saat pembelajaran pembinaan ibadah matrikulasi, metode pembiasaan pada pesantren Sabtu Ahad dan metode praktek lapangan pada pengabdian masyarakat. Selain itu guru PAI juga memberi teguran (perilaku masih wajar) dan memberikan sangsi/hukuman kepada siswa yang melanggar peraturan yang sudah ditetapkan. Adanya pemberian sangsi tidak memberikan penderitaan bagi siswa tetapi justru dapat mengembalikan siswa pada dirinya sendiri. Pemberian sangsi diantaranya menulis ayat Alqur'an dan mengikuti kegiatan pembinaan yang ditinggalkan.

Dalam pembinaan ibadah siswa kelas X MAN Yogyakarta II, guru PAI bekerja sama dengan guru umum yang sudah ditujuk dari madrasah untuk membantu pembinaan ibadah. Adapun jadwal pembagian pembimbing, daftar pemantauan pembinaan ibadah, kriterian penilaian, peraturan, absen, dan semuanya sudah terprogram secara resmi.

Setelah melakukan penelitian dengan berpedoman landasan teori di atas tidak semua peran terlaksana hanya sebagian yaitu enam peran guru PAI dalam pembinaan ibadah siswa kelas X MAN Yogyakarta II. Adapun enam peran guru PAI antara lain mengajar, motivator, mengarahkan, fasilitator, mengevaluasi, dan mendidik.

1. Mengajar yakni dengan memberikan materi berkaitan kaidah tajwid dan pengetahuan ibadah.
2. Memotivasi yakni memberikan dorongan dan semangat agar siswa giat menghafal dan melaksanakan ibadah dengan baik. Adapun peranya yaitu dengan menjelaskan cara menghafal tepat, manfaatnya dan mendatangkan penceramah dari luar.

3. Mengarahkan yakni memberikan bimbingan dan arahan terhadap siswa dalam pelaksanaan pembinaan, agar siswa tersebut mampu belajar, menerapkan dan mengayati pembinaan ibadah. Adapun perannya yakni dengan membimbing bacaan sesuai kaidah tajwid dan menuntun siswa berkaitan dengan target hafalan.

4. Memfasilitasi yakni menyediakan sumber belajar yang cocok dan tidak menjadikan dirinya sebagai satu-satunya sumber belajar yaitu dengan menulis buku panduan pembinaan ibadah siswa yang berisi materi pembinaan ibadah.

5. Mengevaluasi yakni dengan memberikan nilai dan memantau apakah hasilnya terealisasikan atau tidak.

6. Mendidik yakni dengan memberi contoh, membiasakan menjalankan ibadah dan memberi sangsi, jika melanggar aturan.

Dengan diterapkanya pembinaan ibadah di MAN Yogyakarta II yang sudah terprogram, setidaktidaknya pembinaan ibadah siswa dapat memiliki hafalan secara benar sesuai tajwid mulai suratsurat juz ama, doa-doa harian, azdan, iqomah dan kedisiplinan diri siswa dalam ibadah shalat fardhu, shalat sunah berjamah dan tadarus. Meskipun dalam konsep Islam, orang tua (lingkungan keluarga) yang memegang peranan pertama/primer dalam mendidik siswa. Tetapi tidak cukup didikan dari lingkungan keluarga. Mendidik dari sekolah juga penting, karena keduanya saling berkaitan. Hal ini sedana dengan pendapat Zakiah Darajat (1982) menjelaskan bahwa apabila pendidikan agama diabaikan di sekolah, maka didikan agama yang diterima di rumah tidak akan berkembang, bahkan mungkin terhalang, apalagi jika rumah tangga kurang dapat memberikan pembinaan agama sesuai aturannya ${ }^{43}$. Seperti juga Zakiah Darajat (2002)

${ }^{43}$ Zakiah Darajat, Peranan Agama dalam Kesehatan Mental ...,hlm. 71 
apabila seorang anak pada masa itu tidak mendapat pendidikan tentang agama dan tidak mempunyai pengalaman keagamaan, maka nanti setelah dewasa cenderung kepada sikap negative terhadap agama. ${ }^{44}$ Selain itu juga agama sebagai pegangan hidup. Oleh karena itu adanya pembinaan meraka akan tenang dan tentram hatinya karena mereka dapat mendekatkan dan mengabdi kepada dzat yang Maha Kuasa, seperti yang dijelaskan surat Ar-Rad ayat 28 yang berbunyi:

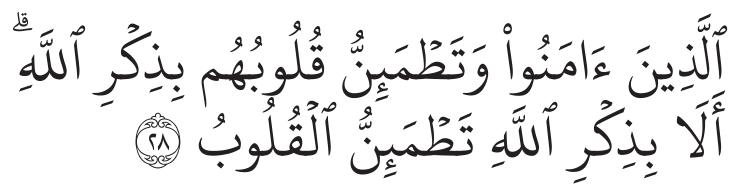

Artinya: "Ketabuilah, babrea banya dengan ingat kepada Allah, hati akan menjadi tentram”.

Dalam melaksanakan suatu program pendidikan ada faktor-faktor yang ikut menentukan berhasilnya atau tidaknya pendidikan tersebut. Menurut Sutari Imam Barnabid (1995) menjelaskan ada lima macam faktor diantaranya: faktor siswa, faktor pendidik, faktor tujuan, faktor alat dan faktor lingkungan. ${ }^{45}$ Berdasarkan landasan teori di atas juga terjadi dalam pembinaan ibadah siswa kelas $\mathrm{X}$, dijumpai hal-hal faktor pendukung dan penghambat.

Adapun beberapa faktor yang menjadi penghambat dan pendukung pembinaan ibadah siswa kelas X MAN Yogyakarta II diantaranya adalah:

1. Faktor pendukung pembinaan ibadah siswa kelas X MAN Yogyakarta II diantaranya:

a. Segi Tujuan

Tujuan merupakan faktor penting karena, untuk mengakhiri suatu usaha dan mengarahkan usaha itu/merupakan titik pangkal dalam mencapai tujuan-tujuan lainnya. Hal ini seperti dengan visi The Real Islamic School.

b. Segi Alat

Guru PAI menulis buku pembinaan yang berjudul "Buku Pembinaan Ibadah Siswa MAN Yogyakarta II". ${ }^{46}$ Buku

\footnotetext{
${ }^{44}$ Zakiah Darajat, Ilmu Jiwa Agama ..., hlm. 69

${ }^{45}$ Sutari Imam Barnadid, Ilmu Pendidikan Sistematis (Yogyakarta, Andi Offset:1995) hlm.35

${ }^{46}$ Hanif Latif, Guru Qur'an Hadist, Tafsir dan
}

pembinaan ini berisi semua materi pembinaan, target-target yang menjadi tanggungannya, dan kriteria penilaian. Sedangkan alat secara tidak langsung dalam mencapai tujuan yaitu mushola dan tempat wudhu.

c. Faktor pendidik

Pihak madrasah telah menunjuk guru umum yang dianggap berkompeten dalam bidang agama untuk membantu dalam pelaksanaan pembinaan ibadah sesuai jadwal yang sudah ditentukan. Semua guru PAI sudah memenuhi standar nasional dengan berijazah S-1 sesuai dengan bidangnya. ${ }^{47}$

d. Adanya peraturan yang ditetapkan oleh TIM Kompetensi Keagamaan.

Dalam pembinaan ibadah ada tata tertib atau peraturan yang sudah disepakati TIM Kompetensi Keagamaan, tujuan diterapkannya untuk mengontrol baik dari kehadiran, target-target yang sudah menjadi tanggungannya.

2. Faktor penghambat pembinaan ibadah siswa kelas X MAN Yogyakarta II diantaranya:

a. Faktor siswa

Salah satu faktor penghambat pembinaan ibadah berdasarkan hasil pengamatan peneliti dan wawancara beberapa pembina diantaranya ada tiga. Pertama, adanya siswa yang belum tuntas bimbingan IQRO, Selain itu juga kondisi fisiknya sudah lelah. ${ }^{48} \mathrm{Kedua}$, ada beberapa siswa menghafal hanya pada saat pelaksanaan pembinaan ibadah. ${ }^{49}$ Ketiga, siswa belum terbiasa menghafalkan surat-surat yang panjang. ${ }^{50}$

Pendamping Pembinaan Ibadah Kelas X MIPA 2, wawancara tanggal 05-November-2015.

${ }^{47}$ Dokumen Profil MAN Yogyakarta II 2015/2016

${ }^{48}$ Hanif Latif, Guru Alqur'an Hadis, Tafsi dan Pendamping Pembinaan Ibadah Kelas X MIPA 2, wawancara tanggal 05-November-2015

${ }^{49}$ Khoerotun Ni'mah, Guru Sejarah Kebudayan Islam dan Pendamping Pembinaan Ibadah Kelas X IPS 1, wawancara tanggal 05-November-2015

${ }^{50}$ Supriyadi, Guru Fikih, dan Pendamping Pembinaan Ibadah Kelas X IIK, wawancara tanggal 04-November-2015. 
b. Faktor lingkungan keluarga

Lingkungan dapat memberikan pengaruh yang positif maupun yang negatif terhadap pertumbuhan jiwanya, dalam sikapnya, dalam akhlaknya maupun dengan perasaan agamanya. Kesibukan orang tua melaksanakan kegiatannya terkadang sampai melupakan tugas untuk mendidik anaknya. Mereka beranggapan tugas pendidikan sepenuhnya telah diserahkan pada pihak sekolah, sehingga sebagian orang tua siswa tidak memantau dan membimbing hafalan.

\section{KESIMPULAN}

Berdasarkan hasil penelitian mengenai Peran Guru PAI Terhadap "Pembinaan Ibadah Siswa" Kelas X MAN Yogyakarta II, maka peneliti mengambil kesimpulan yaitu:

Bentuk-bentuk pembinaan ibadah siswa kelas X diantaranya: pembinaan matrikulasi, pesantren sabtu ahad, pengabdian masyarakat.

Peran guru PAI terhadap pembinaan ibadah siswa kelas $\mathrm{X}$ antara lain: mengajar, memotivasi, mengarahkan, memfasilitas, mengevaluasi, mendidik.

Faktor pendukung dalam proses pembinaan ibadah siswa yaitu: adanya visi MAN Yogyakata II, buku pembinaan ibadah, musalla dan tempat wudhu, keikutsertaan guru umum dalam membantu pembinaan ibadah, adanya peraturan. Sedangkan faktor penghambatnya yaitu adanya siswa yang belum tuntas IQRO serta kondisi fisiknya sudah lelah, siswa menghafal hanya pada saat pelaksanaan pembinaan ibadah, siswa belum terbiasa menghafalkan suratsurat yang panjang, faktor keluarga yang tidak memantau dan membimbing hafalan.

\section{DAFTAR PUSTAKA}

Abuddin Nata Haji. 2010. Ilmu Pendidikan Islam dengan Pendeketan Multidisiplin Normatif Perenialis, Filsafat, Psikologi, Sosiologi, Manajemen, Teknologi, Informasi, Kebudayaan, Politik, Hukum. Jakarta. Raja Grafindo Persada.

Atabik Ali dan Ahmad Zuhdi Muhdlor. 1996. Kamus Kontemporer Arab-Indonesia. Yogyakarta. Mukti Karya Grafik
Buchari Alma dkk. 2010. Guru Profesional Menguasai Metode dan Terampil Mengajar. Bandung. Alfabeta.

Departemen Pendidikan Nasional. 2005. Kamus Besar Bahasa Indonesia. Jakarta. Balai Pustaka. Departemen Pendidikian dan Kebudayaan. 1998. Kamus Besar Babasa Indonesia. Jakarta. Balai Pustaka.

E. Mulyasa. 2007.Menjadi Guru Profesional Menciptakan Pembelajaran Kreatif dan Menyenangkan. Bandung. Remaja Rosdakarya. Fajar Basuki Rahmat dkk. 2015. Buku Pembinaan Ibadah Madrasab Negeri Yogyakarta II. Yogyakarta. MAN Yogyakarta II.

Hamzah. B. Uno dan Masri Kuadrat. 2009. Mengelola Kecerdasan Dalam Pembelajaran Sebuah Konsep Pembelajaran Berbasis Kecerdasan. Jakarta. Bumi aksara.

Ibrahim Shalih. 2011. Fiqib Ibadab Wanita . Jakarta. Amzah

Muhammad Qutub. 1984. Sistem Pendidikan Islam. Bandung. Al-Ma'arif.

M. Abdul Majieb et.el. 1995. Kamus Istilab Fiqib. Jakarta, Pustaka Firdaus.

M. Masrur Huda. 2011. Ternyata Ibadab tidak Hanya Untuk Allah. Jakarta.Qultum Media.

Nasrun Harahap dan Jamil Abu Bakar. 1981. Pengantar Studi kurikulum. Jakarta. Pepara.

Nusa Putra dan Santi Lisnawati. 2012. Penelitian Kualitatif Pendidikan Agama Islam. Bandung. Remaja Rosdakarya.

Sardiman. 2000. Interaksi dan Motivasi Belajar Mengajar. Jakarta. Raja Grafindo Persada.

Sugiyono. 2014. Metode Penelitian Kuantitatif Kualitatif dan D \& R. Bandung. Alfabeta.

Sutari Imam Barnabid. 1995. Ilmu Pendidikan Sistematis. Yogyakarta. Andi Offset.

Undang-Undang Repuplik Indonesia No.14 Tahun 2005. 2006. Tentang Guru dan Dosen. Bandung. Citra Umbara.

Zakiah Daradjat. 1982. Peranan Agama Dalam

Kesehatan Mental. Jakarta.Gunung Agung. 2002. Ilmu Jiwa Agama. Jakarta.

Bulan Bintang. 1995. Pendidikan Islam Dalam

Keluarga dan Sekolah . Jakarta. Ruhama.

Zuhairini dkk. 1981. Metodik Khusus Pendidikan Agama. Surabaya. Usaha Nasional. 